\title{
Direkt restauratív technikák összehasonlítása MOD kavitással rendelkező fogakban üvegszálas anyagok felhasználásával - elözetes tanulmány
}

\author{
DR. SÁRY TEKLA*, DR. NAGY KATALIN**
}

\begin{abstract}
Bevezetés: Kutatásunkban különböző üvegszálas anyagokkal és eltérő direkt technikákkal II. osztályú mezio-okkluzodisztális (MOD) üregekbe elkészített direkt restaurátumokat hasonlítottunk össze statikus törési ellenállási teszt segítségével.

Anyag és módszer: 72 alsó moláris fogat 6 csoportba osztottunk $(n=12)$. A kontrollként szolgáló csoporton kívül az összes fogba II. osztályú MOD kavitásokat fúrtunk, majd ezeket vegyesen üvegszálas hálóval, rövid üvegszálas kompozittal (SFRC) és hagyományos kompozittal restauráltuk. A fogak tesztelése statikus törési ellenállással történt, az értékeket Newtonban regisztráltuk. A létrejött törés mintázatát is értékeltük.

Eredmények: Az ép fogak $(2099 \pm 351,04$ N), a 3. (SFRC $-1645 \pm 457$ N) és 6. csoportok (körkörösen elhelyezett üvegszálas háló - $2019 \pm 352$ N) értékei között nem volt szignifikáns különbség.

Megbeszélés: A mechanikai tesztelés eredményeként leginkább a körkörösen elhelyezett üvegszálas hálóval restaurált csoport értékei közelítették meg az ép fogak törési ellenállási értékeit. A hagyományos kompozit restaurátummal ellátott fogak szignifikánsan gyengébben teljesítettek, mint a kontroll csoport fogai.
\end{abstract}

Kulcsszavak: MOD kavitás, kompozit tömés, rövid üvegszálas kompozit, üvegszálas háló

\section{Bevezetés}

A modern adhezív alapokon nyugvó biomimetikus fogászatban a helyreállítani kívánt fognak és az elkészített restaurátumnak strukturális egységet kell alkotnia, ami így a szájüregben hosszú távon képes lesz ellenállni a több irányú, ismétlődő terheléseknek [1]. Moláris fogakra restaurálhatóság szempontjából általánosan igaz, hogy minél több felszínre terjed az anyaghiány - így a restaurátum is - és minél szélesebb a kavitás orovesztibuláris kiterjedése, annál nagyobb a valószínüsége, hogy idővel csücsöktörés következik be [5]. Számos tanulmány bizonyítja, hogy a megmaradó foganyagban szétoszló stressz nagyságát egyértelmüen meghatározza a kialakított üreg formája, az üreg mérete és mélysége, valamint a megmaradt falak száma [18].

Reeh és munkatársai szerint kritikus a zárólécek megőrzése mechanikai szempontból, amit a restaurátum sikerességének kulcsaként említettek cikkükben [23]. Gonzalez-Lopez és munkatársai kutatásából kiderül, hogy II. osztályú mezio-okkluzális / okkluzo-disztális (MO/ OD) üreghez képest a mezio-okkluzo-disztális (MOD) üregekben drámaian megnő a csücskök elhajlása [13]. Ennek oka a zárólécek elvesztése, amelyek összetarta- nák a szemben lévő falakat a rágóerőkkel szemben, így ilyen esetben a fog töréssel szembeni ellenállása szignifikánsan lecsökken [15]. Az említett okok miatt meggyengült MOD üreget lehetőségünk van direkt és indirekt módon helyreállítani. Bár az indirekt restaurátumok tartós, jó megoldást jelenthetnek, főleg a mélyebb MOD kavitások ellátására, felmerülnek esetükben bizonyos hátrányok is (pl. az elkészítésükhöz szükséges hoszszabb időtartam, költségesebb), amelyek korlátozhatják alkalmazásukat. Ezzel szemben a direkt helyreálítás jóval gyorsabb és anyagilag kedvezőbb megoldást jelenthet a páciensek számára. Direkt restauratív technika választása esetén leggyakrabban a mély MOD üreggel rendelkező fogat egy hagyományos kompozit vagy amalgám töméssel szokták ellátni a napi praxisban. Bár az említett direkt restaurátumok a klinikumban sikeresnek mondhatók $[2,17]$, ugyanakkor egyik anyag sem teljesen ideális egy ilyen meggyengült kavitás ellátására. In vitro biomechanikai témájú vizsgálatok azt találták, hogy az amalgám nem nyújt elegendő megerősítést egy MOD kavitás esetében $[33,19]$, és sokszor a megmaradt falak megrepedéséhez és töréséhez vezethet. Ugyanakkor Forster és munkatársai in vitro vizsgálatukban azt találták, hogy mélyebb MOD ka- 
vitások esetén a hagyományos kompozit tömés sem képes megerősíteni a fogat és visszaadni az egészséges foggal azonos töréssel szembeni ellenállás értéket [8]. Ennek a hátterében számos tényező áll, ezek egy része az alkalmazott restauratív anyagra (polimerizációs zsugorodás, töréssel szembeni szívósság), egy része pedig az operátorra (izolálás, alkalmazott ragasztási és applikációs technika stb.) vezethető vissza. Lehetséges hatékonyabb direkt megerősítés, érdekében van lehetőség üvegszálas anyagok használatára a hagyományos kompozit anyagokat kiegészítve. Ilyen lehet például egy üvegszálas háló vagy akár rövid üvegszál megerősítésű kompozit (short-fiber reinforced composite, SFRC). Mivel a rövid üvegszállal megerősített kompozitokkal még csak rövid távú publikált klinikai tapasztalat áll rendelkezésre [30], javasolt az említett anyag mind in vivo, mind in vitro tesztelése különböző szituációkban.

Jelen vizsgálat célja, hogy felmérje az üvegszálas anyagok új kombinációjával létrehozott direkt restaurátumok potenciális megerősítő hatását mély MOD kavitások esetében. A nullhipotézisek a következők: 1. a töréssel szembeni ellenállás értékek tekintetében nincs különbség a különböző üvegszálas anyagokkal restaurált fogak és az egészséges fogak között. 2. az üvegszálas anyagok alkalmazása nem befolyásolta a fogak törésmintázatát.

\section{Vizsgálati anyag és módszer}

Kutatásunkhoz 72 parodontológiai vagy orthodonciai okból eltávolított, koronálisan ép harmadik moláris fogakat használtunk fel. A fogakat fiziológiás sóoldatban szobahőmérsékleten tároltuk és az eltávolítást követő 6 hónapon belül felhasználtuk. Az összes fogat egy operátor készítette elő. Kizárási kritériumnak számított: koronai vagy gyökéri szuvasság, vagy repedés, vagy látható rezorpció. A repedés meglétét szabad szemmel direkt megvilágítás mellett vizsgáltuk. A kiválasztott fogak 80\%-a bukko-lingválisan mérve 10,0-10,9 mm volt, a fennmaradó fogak pedig a 11,0-12,0 mm tartományba estek. A mezio-disztális átmérőt megmérve mindössze $10 \%$ eltérést engedélyeztünk a saját átlagukhoz képest. A kiválasztott fogakat véletlenszerüen 6 csoportra osztottuk $(n=12)$.

\section{Üregkialakítás}

Az 1. csoportba tartozó fogakat érintetlenül hagytuk, ez később kontrollként szolgált a mechanikai tesztelés során. A többi csoportba tartozó fogakba standardizált, a fog tengelyével párhuzamos falú üregeket alakítottunk ki: II. osztályú MOD kavitásokat 2,5 mm-es falvastagsággal és $5 \mathrm{~mm}$-es mélységgel (csücsökcsúcshoz képest), amelyet egy korona-falvastagságmérő és egy hagyományos parodontológiai szonda (Hu-Friedy Mfg. Co., Chicago, USA) segítségével kontrolláltunk [8]. A kavitás mélységét mindig a kavitás adott részéhez tartozó csücsök csúcsától mértük úgy, hogy a parodontológiai szonda érintkezzen az axiális fallal. Az 1. táblázat tartalmazza a tömések elkészítése során használt anyagokat. Az összes mintafogat ugyanazzal az adhezív kezeléssel készítettük elő. Először egy Toffelmire matricát erősítettünk a fogra (1101C 0,035, Hawe-Neos, Olaszország), majd szelektív zománcsavazás után (37\%-os orthofoszforsav $15 \mathrm{mp}$-ig) lemostuk és leszárítottuk a fogakat. Az adhezív kezelést G-Premio Bonddal (GC Europe, Leuven, Belgium), a gyártó utasításait követve végeztük. A felvitt réteget $40 \mathrm{mp}$-ig fotopolimerizáltuk Optilux 501 halogén lámpával standard üzemmódban 740 +/- 36 mWcm²-es fényintenzitáson. Ezt követően az üreg aljára egy nagyjából $0,5 \mathrm{~mm}$ vastag folyékony kompozit réteget applikáltunk (G-aenial Flo, GC Europe, Leuven, Belgium), amelyet szintén (mint a későbbi restauratív lépések során is minden réteget) $40 \mathrm{mp}$ ig fotopolimerizáltunk. Ezt követően a fogak hiányzó meziális és disztális falait centripetális technikával felépítettük hagyományos kompozittal (G-aenial Posterior PJ-E, GC Europe, Leuven, Belgium), ezzel az eredetileg II. osztályú üreget I. osztályúvá változtatva, majd az alábbiak szerint direkt restaurátummal láttuk el őket:

2. csoport: az üregeket hagyományos kompozit töméssel láttuk el ferde rétegzési technikával, nagyjából $2 \mathrm{~mm}$-es rétegvastagsággal rétegenként (G-aenial Posterior PJ-E, GC Europe, Leuven, Belgium).

3. csoport: az üregeket egy rövid üvegszál megerősítésű kompozittal (SFRC, EverX Posterior, GC Europe, Leuven, Belgium) töltöttük fel egyetlen rétegben, bulkfill technikával.

4. csoport: egy előre méretre vágott, előimpregnált üvegszálas hálót (Everstick NET, GC Europe, Leuven, Belgium) helyeztünk bukko-lingválisan az üreg aljára fektetve úgy, hogy az axiális falakhoz hozzásimuljon,

\section{1. táblázat}

A direkt restaurátumok elkészítéséhez felhasznált anyagok listája.

\begin{tabular}{|l|l|l|}
\hline Felhasznált anyag & Jellemző & Gyártó \\
\hline G-Premio Bond & Önsavazó, egy komponensű univerzális adhezív & GC Europe, Leuven, Belgium \\
\hline StickRESIN & Zománc adhezív & GC Europe, Leuven, Belgium \\
\hline Gradia Direct Flo & Mikrotöltésű folyékony kompozit & GC Europe, Leuven, Belgium \\
\hline G-aenial Posterior & Mikrohibrid paszta kompozit & GC Europe, Leuven, Belgium \\
\hline everX Posterior & Rövid üvegszál megerősítésű kompozit & GC Europe, Leuven, Belgium \\
\hline everStick NET & Kétirányú előimpregnált üvegszálas háló & GC Europe, Leuven, Belgium \\
\hline
\end{tabular}


de ne érje el a kavitás széleit. A hálót egy múgyantával (Stick resin, GC Europe, Leuven, Belgium) enyhén nedvesített parodontológiai szonda (Hu-Friedy Mfg. Co., Chicago, USA) segítségével adaptáltuk az üreg falaihoz. 40 mp megvilágítás után az üreget SFRC-vel töltöttük fel.

5. csoport: az üregeket az adhezív kezelést követően SFRC-vel töltöttük fel egyetlen rétegben, bulk-fill technikával, amíg el nem értük a kavitás szélétől mért kb. 1,5-2 mm-t. Ekkor egy méretre vágott ( $\mathrm{kb}$. a fennmaradó üreg nagyságának megfelelő) előimpregnált üvegszálas hálót helyeztünk a restaurátum tetejére bukkolingvális irányba fektetve úgy, hogy a háló sehol ne érje el az üreg széleit, majd $40 \mathrm{mp}$-ig fotopolimerizáltuk.

6. csoport: ebben a csoportban 2 darab előimpregnált üvegszálas hálót körkörösen adaptáltuk az üreg falaihoz úgy, hogy az teljesen körbeérjen a falakon. A megvilágítás után a fennmaradó teret SFRC-vel töltöttük fel.

Az SFRC-t minden esetben $40 \mathrm{mp}$-ig fotopolimerizáltuk. Az üvegszálas anyagokkal ellátott csoportokban az okkluzálisan fennmaradó, nagyjából $1 \mathrm{~mm}$-es részt a gyártó utasításait követve hagyományos kompozittal fedtük le (G-aenial Posterior PJ-E, GC Europe, Leuven, Belgium). A restaurátumok finírozása és polírozása megegyezett az összes csoportnál: a finírozáshoz egy finom szemcséjü gyémántfúrót (FG 7406-018, Jet Diamonds, USA and FG 249-F012, Horico, Németország), a polírozáshoz pedig alumínium-oxid polírozót használtunk.

Az összes mintafog gyökérfelszínét egy rugalmas szeparáló anyaggal vontuk be a parodontális ligamentumokat szimulálva (Rubber-Sep, Kerr, Orange, CA), majd a mintákat a zománc-cement határtól apikálisan
$2 \mathrm{~mm}$-re meghatározott szintig beágyaztuk speciális beágyazó múgyantába (Technovit 4004, Heraeus-Kulzer). A mintákat statikus törési ellenállási tesztnek vetettük alá (5848 MicroTester1, Instron, Norwood, MA, USA), és törésig terheltük őket. $A$ terhelést egy $6 \mathrm{~mm}$ átmérőjü gömb formájú fejjel végeztük, melyet az okkluzális felszín közepére pozícionáltunk, és a fogakat tengelyirányuknak megfelelően, függőlegesen terheltük. A mechanikai tesztelést $2 \mathrm{~mm} /$ perc sebességgel végeztük, a töréssel szembeni ellenállást, azaz a törést okozó maximális terhelést Newtonban $(\mathrm{N})$ regisztráltuk. A mechanikai tesztelés után megvizsgáltuk a törési mintázatot. Az elkülönítést (restaurálható és nem restaurálható törés) Scotti és munkatársai ajánlása alapján végeztük [25]. A létrejött törés akkor mondható restaurálhatónak, ha a törés a zománc-cement junkció (cementoenamel junction, CEJ) szintjében vagy fölötte végződik, míg a CEJ alatt végződő kedvezőtlennek és nem restaurálhatónak minősül. A statisztikai elemzést SPSS 17,0 programmal végeztük el. A csoportok összehasonlítását KruskalWallis ANOVA-val végeztük, amit Tukey páronkénti öszszehasonlítással egészítettünk ki.

\section{Eredmények}

A mechanikai tesztelés eredményeinek leíró statisztikáját az 2. táblázat mutatja. A legmagasabb statikus törési ellenállási értékekkel a természetes fogak rendelkeztek (1. csoport; $2099 \pm 351,04$ N). Az ép fogakhoz képest a restaurált csoportok közül szignifikánsan gyengébbnek bizonyultak a hagyományos kompozit töméssel ellátott (2. csoport) $(p=0,031)$, és az üveg-

\section{2. táblázat}

Az egyes csoportokra jellemzö átlagos töréssel szembeni ellenállás-értékek Newtonban jelölve, valamint a csoportok közötti szignifikáns eltérések pirossal jelölve.

A csoportok összehasonlítását Kruskal-Wallis ANOVA-val végeztük, amelyet Tukey páronkénti összehasonlítással egészítettünk ki.

\begin{tabular}{|l|c|c|c|c|c|c|}
\hline $\begin{array}{l}\text { Statikus törési } \\
\text { ellenállás }\end{array}$ & $\begin{array}{l}\mathbf{1 .} \text { csoport } \\
(2099,7 \mathrm{~N})\end{array}$ & $\begin{array}{l}\mathbf{2 .} \text { csoport } \\
(1503,1 \mathrm{~N})\end{array}$ & $\begin{array}{l}\text { 3. csoport } \\
(1645,5 \mathrm{~N})\end{array}$ & $\begin{array}{l}\mathbf{4} \text { csoport } \\
(1015,3 \mathrm{~N})\end{array}$ & $\begin{array}{l}\mathbf{5} \text { csoport } \\
(1400,6 \mathrm{~N})\end{array}$ & $\begin{array}{l}\mathbf{6} \text {. csoport } \\
(2019,3 \mathrm{~N})\end{array}$ \\
\hline 1. csoport & & $\mathbf{0 , 0 3 1 0 0 6}$ & 0,196546 & $\mathbf{0 , 0 0 0 1 2 6}$ & $\mathbf{0 , 0 0 6 0 0 0}$ & 0,999519 \\
\hline 2. csoport & $\mathbf{0 , 0 3 1 0 0 6}$ & & 0,987611 & 0,134090 & 0,997960 & 0,094568 \\
\hline 3. csoport & 0,196546 & 0,987611 & & $\mathbf{0 , 0 1 8 5 3 5}$ & 0,842539 & 0,418231 \\
\hline 4. csoport & $\mathbf{0 , 0 0 0 1 2 6}$ & 0,134090 & $\mathbf{0 , 0 1 8 5 3 5}$ & & 0,380623 & $\mathbf{0 , 0 0 0 1 3 6}$ \\
\hline 5. csoport & $\mathbf{0 , 0 0 6 0 0 0}$ & 0,997960 & 0,842539 & 0,380623 & & $\mathbf{0 , 0 2 2 1 8 4}$ \\
\hline 6. csoport & 0,999519 & 0,094568 & 0,418231 & $\mathbf{0 , 0 0 0 1 3 6}$ & $\mathbf{0 , 0 2 2 1 8 4}$ & \\
\hline
\end{tabular}

Törési mintázat megoszlása a csoportokon belül (darab).

\begin{tabular}{|l|c|c|c|c|c|c|}
\hline Törésmintázat & 1. csoport & 2. csoport & 3. csoport & 4. csoport & 5. csoport & 6. csoport \\
\hline Helyreállítható & 11 & 5 & 9 & 7 & 9 & 7 \\
\hline Nem helyreállítható & 1 & 7 & 3 & 5 & 3 & 5 \\
\hline
\end{tabular}


szálas hálóval restaurált csoportok közül azok, amelyekben a hálót az üreg aljára, illetve az üreg tetejére fektettük (4., 5. csoport) ( $p=0,000, p=0,006)$. Ugyanakkor az SFRC-vel restaurált 3. csoport és a körkörösen adaptált üvegszálas háló segítségével helyreállított 6. csoport értékei nem mutattak szignifikáns eltérést a kontrollcsoporthoz képest.

A törésmintázat szempontjából (3. táblázat) a legjobb arányban az intakt fogak mutattak helyreállítható törésmintázatot. A restaurált csoportoknál a vizsgálat során használt üvegszálas anyagok alkalmazása dominánsan helyreállítható törésmintázat felé tolja az arányokat, míg a hagyományos kompozittal helyreállított csoport döntően nem restaurálható törést eredményezett.

\section{Megbeszélés}

Kutatásunkban mély MOD üreggel rendelkező fogakat különböző direkt restauratív technikával állítottunk helyre. Üregeink méretét úgy határoztuk meg, hogy az mindennapi szituációkat modellezzen - pl. amalgámtömés cseréjekor preparált nagy MOD üregek. Bevált mindennapi terápia az ilyen üreggel rendelkező fogaknál egy hagyományos kompozit tömés készítése, azonban itt, a nagy mennyiségű kompozit tömőanyag alkalmazása miatt, jelentős zsugorodással és ennek következtében fellépő stresszel kell számolnunk [22]. Ennek következményei lehetnek: a tömőanyag elválása a ragasztási felülettől, mikro szivárgás, szekunder káriesz vagy a csücskök jelentős flexiója és következményes zománcrepedés [22, 29]. Ezenkívül fontos probléma, hogy a hagyományos kompozit tömőanyagok töréssel szembeni szívóssága (fracture toughness) szignifikánsan elmarad az általa helyettesíteni kívánt dentin értékeitől [7]. Lasilla és munkatársai megfogalmazták, hogy a töréssel szembeni szívósság egy törékeny anyag terhelés alatt létrejött repedéssel szembeni ellenállását, a repedés megállítási képességét jelenti, ezáltal jól jelzi az anyag fáradással szembeni ellenállását és tartósságát [14]. Ezen tulajdonság hiánya a kompozitok esetében leggyakrabban nagy kiterjedésű töméseknél észlelhető, ugyanis ilyenkor kritikus a felhasznált anyag volumene [4]. Ezen anyagtani tulajdonságokból arra következtethetünk, hogy a hagyományos kompozit nem feltétlenül a legoptimálisabb választás mély MOD kavitások ellátására. Eredményeink is alátámasztják ezt, a kompozittal ferdén rétegezve felépített mintafogak (2. csoport) szignifikánsan alacsonyabb töréssel szembeni ellenállás-értékeket mutattak, mint a kontrollként szolgáló ép fogak $(p=0,031)$. Forster és munkatársai hasonló megállapításra jutottak nem gyökérkezelt, mély MOD üreggel rendelkező moláris fogak direkt kompozit töméssel történő ellátása esetén [8]. Papadopoulos és munkatársai is hasonló eredményeket kaptak, azonban ők a vizsgálatukban az MOD üregeket bulk fill kompozittal restaurálták [21]. A kompozit tömések töréssel szembeni elégtelen szí- vósságát jól mutatja a minták törésmintázata, ugyanis a 2. csoport túlnyomóan nem helyreállítható törésmintázatot mutatott. A stresszelnyelés és a repedés megállítása a fogakban lényegében a dentin-zománc junkció (DEJ) és a közvetlen alatta található dentin rétegében történik. Minél nagyobb a koronai struktúrában az anyagveszteség, annál kevesebb a visszamaradó DEJ és dentin mennyisége, így nő az esély a restaurátum katasztrofális, nem restaurálható törésére. Az SFRC magas stressznek és terhelésnek kitett szituációkba lett tervezve [11]. Kutatások szerint az SFRC kompressziós és fáradásos teszteléseknek egyaránt hatékonyabban képes ellenállni, mint a hagyományos kompozitok, ráadásul a töréssel szembeni szívóssága is magasabb [3]. Ezen tulajdonságait a benne található üvegszálak rövid méretének és a szemi-interpenetráló polimerhálózatnak köszönheti [12]. Vizsgálatunkban a tisztán SFRC-vel felépített fogak értékei nem tértek el szignifikánsan a kontroll, ép fogak értékeitől. Ráadásul a törésmintázat is kedvezően alakult ebben a csoportban (az összes restaurált csoport közül a legmagasabb számban produkált kedvező töréseket). Ez megegyezik Fráter és munkatársainak megállapításaival, bár ők sekélyebb MOD kavitásokat restauráltak vizsgálatukban [9]. Kutatásunkban az SFRC-t biomimetikus "rétegzés" szerint alkalmaztuk, azaz a hiányzó teljes mennyiségü dentin helyére lett applikálva és az eredeti DEJ szintjéig terjedt az üregben. Gyakorlati szempontból fontos megemlíteni, hogy jelen vizsgálatban, a gyártó utasításainak megfelelően, az SFRC-t bulk fill anyagként egy rétegben helyeztük a kavitásba. Vizsgálatok bizonyítják, hogy az SFRC transzparens tulajdonsága és a rövid üvegszálak fényvezető tulajdonsága által az anyagot 4-5 mm mélységig át lehet megfelelően világítani, fotopolimerizálni [10, 16].

A mély MOD kavitással rendelkező fogak esetén jelentős csücsökelhajlás figyelhető meg a hiányzó zárólécek miatt, mely falak a későbbiekben hajlamosak a megrepedésre, törésre [28]. A megmaradt falak stabilizálására alkalmasak lehetnek üvegszálak vagy egyéb rostok mint belső sínező elemek. Vizsgálatunkban egy üvegszálas hálót használtunk (Everstick NET, GC Europe, Leuven, Belgium), melyet a kavitásokban csoportonként eltérően pozícionálva próbáltuk minél hatékonyabban megerősíteni a direkt restaurátumot és a fogat. Turkaslan és munkatársai megállapították, hogy egy előimpregnált üvegszálas háló a fogakat két iránynyal szemben képes megerősíteni, illetve képes megállítani a repedések terjedését [31]. Az irodalomban eddig restauratív célokra az Everstick NET-et csak indirekt restaurátum (endokorona, héj) alá használták [24, 32], viszont poszterior kavitásokban direkt restauratív célokra még nem. Vizsgálatunkban az üvegszálas háló csak cirkumferenciálisan (6. csoport) alkalmazva volt képes megerősíteni a fogakat, azaz nem különbözött töréssel szembeni ellenállás tekintetében az ép fogaktól. Ugyanakkor a kavitás alján (4. csoport) vagy a tömés tetején (5. csoport) használt üvegszálas háló szignifi- 
kánsan kisebb töréssel szembeni ellenállást produkált ( $p=0,000, p=0,006)$, mint az ép fogak, azaz nem erősítette meg azt. Érdekes, hogy az üvegszálas háló nem cirkumferenciálisan alkalmazva SFRC-vel együtt nem adott jobb eredményt, mint a ferdén rétegzett kompozittal (2. csoport) vagy az üvegszálas háló nélkül, SFRCvel restaurált fogak (3. csoport). Ez ellentmond Oskoee és munkatársai eredményeinek, mely szerint az üvegszálas háló MOD kavitásban „okkluzális pozicionálva” képes jelentős megerősítést létrehozni [20]. Feltételezzük, hogy az SFRC izotróp tulajdonsága, ami által a véletlenszerüen rendeződő rostok minden irányban képesek megerősítést végezni, önmagában jótékony hatású, üvegszálas háló nélkül is. Továbbá elképzelhető, hogy az SFRC adaptációja a kavitás falaihoz jobb lehet üvegszálas háló nélkül, mint hálóval együttesen. Jelen vizsgálatban minden restaurált csoportban a kavitások aljára egy vékony folyékony kompozit réteget helyeztünk a direkt restaurátumok alá. A folyékony kompozit alkalmazása elasztikus alapként hasznosnak bizonyult a direkt poszterior kompozit tömések esetében a legtöbb esetben [6, 26]. Bár arra ez idáig nincs tudomásunk szerint kutatás, hogy az SFRC alá is előnyös lenne az alkalmazása, viszont saját tapasztalatunk szerint könnyebbé teszi az SFRC adaptálását. Továbbá a kutatás standardizálása érdekében szükségesnek ítéltük minden csoportban alkalmazni, ha már a direkt kompozit tömések esetén alkalmaztuk. A törésmintázat tekintetében, függetlenül az üvegszálas anyag milyenségétől (SFRC önmagában vagy SFRC hálóval együtt) vagy annak kavitáson belüli pozíciójától, jelen üvegszálas anyagok minden esetben döntően helyreállítható törésmintázatot eredményeztek. Így a restaurátum idővel létrejövő sikertelensége esetén a fog újra restaurálható lesz direkt vagy esetleg indirekt megoldásokkal.

Vizsgálatunkban a restaurált fogakat statikus törési tesztnek vetettük alá. Szabó és munkatársainak vizsgálata arra enged következtetni, hogy mechanikai tesztelések során a beágyazás szintje, azaz a szimulált csontos megtámasztás is befolyásolhatja a töréssel szembeni ellenállást és a törés mintázatát [27]. Vizsgálatunkban a mintafogakat ép parodontális viszonyokat szimulálva ágyaztuk be. Vizsgálatunk limitjeként megemlítendő a statikus törési teszt alkalmazása, amely inkább egy idegen tárgyra harapás vagy traumás sérülés esetét szimulálja, mintsem a rágáskor fellépő dinamikus terhelés szituációját. Kutatásunkat a későbbiekben szándékozunk nagyobb elemszámmal is elvégezni és dinamikus terhelést is alkalmazni a restaurátumok minél élethübb tesztelése érdekében.

\section{Konklúzió}

1. Eredményeink alapján mély MOD kavitások megerősíthetőek direkt tömésekkel, amelyeket rövid üvegszálas kompozittal vagy ezt kiegészítve körkörösen adaptált üvegszálas hálóval készíthetünk el.
2. Jelen vizsgálatban a mély MOD kavitások esetén a rövid üvegszálas kompozit önmagában vagy üvegszálas hálóval együtt alkalmazva döntően helyreállítható törésmintázatot eredményezett.

3. Jelen vizsgálatban a mély MOD kavitások esetén a hagyományos, ferdén rétegzett kompozit tömés döntően nem restaurálható törésmintázatot eredményezett.

\section{Irodalom}

1. Bazos $P$, Magne $P$ : Bio-emulation: biomimetically emulating nature utilizing a histo-anatomic approach; structural analysis. Eur $J$ Esthet Dent 2011; 8-19.

2. Beck F, Letther S, Graf A, Bitriol B, Dumitrescu N, Bauer P és mtsai: Survival of direct resin restorations in posterior teeth within a 19-year period (1996-2015): A meta-analysis of prospective studies. Dent Mater 2015; 958-985. https://doi.org/10.1016/j. dental.2015.05.004

3. Bijelic-Donova J, Garoushi S, Vallittu Pk, Lassila LV: Mechanical properties, fracture resistance, and fatigue limits of short fiber reinforced dental composite resin. J Prosthet Dent 2016; 95-102. https://doi.org/10.1016/j.prosdent.2015.07.012

4. Braga Rr, Boaro LC, Kuroe T, Azevedo CL, Singer JM: Influence of cavity dimensions and their derivatives (volume and 'C' factor) on shrinkage stress development and microleakage of composite restorations. Dent Mater 2006; 818-823. https://doi .org/10.1016/j.dental.2005.11.010

5. Cavel WT, Kelsey WP, Blankenau RJ: An in vivo study of cuspal fracture. J Prosthet Dent 1985; 38-42. https://doi.org/10.2307/ 3192894

6. DELIPERI S: Functional and aesthetic guidelines for stress-reduced direct posterior composite restorations. Oper Dent 2012; 425-431. https://doi.org/10.2341/11-082-T

7. Deliperi S, Alleman D, Rudo D: Stress-reduced Direct Composites for the Restoration of Structurally Compromised Teeth: Fiber Design According to the "Wallpapering" Technique. Oper Dent 2017; 233-243. https://doi.org/10.2341/15-289-T

8. Forster A, Braunitzer G, Tóth M, Szabó BP, Fráter M: In Vitro Fracture Resistance of Adhesively Restored Molar Teeth with Different MOD Cavity Dimensions. J Prosthodont 2019; 325-331.

9. Fráter M, Forster A, Keresztúri M, Braunitzer G, Nagy K: In vitro fracture resistance of molar teeth restored with a short fibre-reinforced composite material. J Dent 2014; 1143-1150. https://doi .org/10.1016/j.jdent.2014.05.004

10. Fráter M, Lassila L, Braunitzer G, Vallittu PK, Garoushi S: Fracture resistance and marginal gap formation of post-core restorations: influence of different fiber-reinforced composites. Clin Oral Investig 2019 May 16. doi: 10.1007/s00784-019-02902-3. [Epub ahead of print] https://doi.org/10.1007/s00784-019-02902-3

11. Garoushi S, Sallynoja E, Vallittu PK, Lassila L: Physical properties and depth of cure of a new short fiber reinforced composite. Dent Mater 2013; 835-841. https://doi.org/10.1016/j.dental .2013.04.016

12. Garoushi S, Gargoum A, Vallittu PK, Lassila L: Short fiber-reinforced composite restorations: A review of the current literature. J Investig Clin Dent 2018; 123-130. https://doi.org/10.1111/ jicd. 12330

13. González-Lopez S, De Haro-Gasquet F, Vílchez-Díaz MA, CebalLOS L, BRAVO M: Effect of restorative procedures and occlusal loading on cuspal deflection. Oper Dent 2006; 33-38. https://doi .org/10.2341/04-165

14. Lassila L, Keulemans F, Sailynoja E, Vallittu PK, Garoushi S: Mechanical properties and fracture behavior of flowable fiber reinforced composite restorations. Dent Mater 2018; 598-606. https://doi.org/10.1016/j.dental.2018.01.002 
15. Lee MR, Cho BH, Son HH, Um CM, Lee IB: Influence of cavity dimension and restoration methods on the cusp deflection of premolars in composite restoration. Dent Mater 2007; 288-295.

16. Lempel E, Öri Z, Szalma J, Lovász BV, Kiss A, Tóth Á, KunságiMÁTÉ S: Effect of exposure time and pre-heating on the conversion degree of conventional, bulk-fill, fiber reinforced and polyacid-modified resin composites. Dent Mater 2019; 217-228. https:// doi.org/10.1016/j.dental.2018.11.017

17. Lempel E, Tóth Á, Fábián T, Krajcár K, Szalma J: Retrospective evaluation of posterior direct composite restorations: 10-year findings. Dent Mater 2015; 115-122. https://doi.org/10.1016/ j.dental.2014.11.001

18. LIN CL, ChANG CH, Ko CC: Multifactorial analysis of an MOD restored human premolar using auto-mesh finite element approach J Oral Rehabil 2001; 576-585.

19. Magne $P$, Oganesyan T: CT scan-based finite element analysis of premolar cuspal deflection following operative procedures. Int J Periodontics Restorative Dent 2009; 361-369.

20. Oskoee PA, Ajami AA, Navimipour EJ, Oskoee SS, Sadjadi J: The effect of three composite fiber insertion techniques on fracture resistance of root-filled teeth. J Endod 2009; 413-416. https://doi .org/10.1016/j.joen.2008.11.027

21. Papadopoluos C, Dionysopoulos D, Tolidis K, Kouros P, KoliNIOTOU-Koumpia E, Tsitrou EA: Structural Integrity Evaluation of Large MOD Restorations Fabricated With a Bulk-Fill and a CAD/CAM Resin Composite Material. Oper Dent 2019; 312-321. https://doi.org/10.2341/18-013-L

22. Plotino G, Buono L, Grande NM, Lamorgese V, Somma F: Fracture resistance of endodontically treated molars restored with extensive composite resin restorations. J Prosthet Dent 2008; 225-232. https://doi.org/10.1016/S0022-3913(08)60047-5

23. Reeh ES, Messer HH, Douglas WH: Reduction in tooth stiffness as a result of endodontic and restorative procedures. $J$ Endod 1989; 512-516. https://doi.org/10.1016/S0099-2399(89)80191-8

24. Rocca GT, Saratti CM, Poncet A, Feilzer AJ, Krejcl I: The influence of FRCs reinforcement on marginal adaptation of CAD/CAM composite resin endocrowns after simulated fatigue loading.
Odontology 2016; 220-232. https://doi.org/10.1007/s10266-015 $-0202-9$

25. Scotti N, Coero Borga FA, Alovisi M, Rota R, Pasqualini D, BERUTTI E: Is fracture resistance of endodontically treated mandibular molars restored with indirect onlay composite restorations influenced by fibre post insertion? J Dent 2012; 814-820. https:// doi.org/10.1016/j.jdent.2012.06.005

26. Soares CJ, Faria-E-Silva AL, Rodrigues MP, Vilela ABF, PfeifER CS, TANTBIROJn D és mtsai: Polymerization shrinkage stress of composite resins and resin cements - What do we need to know? Braz Oral Res 2017; 49-63. https://doi.org/10.1590/1807 -3107bor-2017.vol31.0062

27. Szabó B, EÖrdegh G, Szabó PB, Fráter M: In vitro fracture resistance of root amputated molar teeth restored with overlay a pilot study. Fogorv Szle 2017; 111-116.

28. Taha NA, Palamara Je, Messer HH: Cuspal deflection, strain and microleakage of endodontically treated premolar teeth restored with direct resin composites. J Dent 2009; 724-730. https://doi .org/10.1016/j.jdent.2009.05.027

29. Taha NA, Palamara JE, Messer HH: Fracture strength and fracture patterns of root filled teeth restored with direct resin restorations. J Dent 2011; 527-535. https://doi.org/10.1016/j.jdent.2011 .05 .003

30. Tanner J, Tolvanen M, Garoushi S, Sailynoja E: Clinical evaluation of fiber-reinforced composite restorations in posterior teeth results of 2.5 year follow-up. Open Dent J 2018; 476-485. https:// doi.org/10.2174/1874210601812010476

31. Turkaslan S, Tezvergil-Mutluay A, Bagis B, Vallittu PK, Lassila LV: Effect of fiber-reinforced composites on the failure load and failure mode of composite veneers. Dent Mater J 2009; 530-536. https://doi.org/10.4012/dmj.28.530

32. ValLITTU PK: Use of woven glass fibres to reinforce a composite veneer. A fracture resistance and acoustic emission study. J Oral Rehabil 2002; 423-429. https://doi.org/10.1046/j.1365-2842 .2002.00915.x

33. Versluis A, Versluis-Tantbirojn D: Filling cavities or restoring teeth? J Tenn Dent Assoc 2011; 36-42.

T SÁRY, K NAGY

\section{Comparing direct restorations utilising fiber reinforced materials in MOD cavities - pilot study}

Objectives: The aim of this preliminary in vitro study was to compare the efficiency of different direct restorative techniques for restoring class II. MOD cavities in molar teeth.

Methods: seventy two mandibular third molars were divided into 6 groups $(n=12)$. Except for the control group (intact teeth, Group 1), in all other groups deep MOD cavities were prepared. The cavities were restored by different direct restorative techniques (Group 2-6). Group 2: conventional resin-based composite (RBC), Group 3: replacing the missing dentine with short-fiber reinforced composite (SFRC) and occlusally covered with $1 \mathrm{~mm}$ RBC, Group 4: fiber net inserted in a buccal to lingual direction placed on the base of the cavity and finished with SFRC and RBC, Group 5: SFRC with fiber net placed on top of it in a buccal to lingual direction and finished with RBC, Group 6: fiber net placed circumferentially into the cavity and finished with SFRC and RBC. The specimens were submitted to static load to fracture test.

Results: the intact teeth (Group 1) yielded the highest fracture resistance values among all groups. There was no statistically significant difference between Group 1, 3 and 6. In all groups, the fracture pattern was mostly restorable, except for Group 2 showing non restorable fractures predominantly.

Conclusions: The application of fiber net circumferentially with SFRC produced fracture resistance values closly resembling the values with intact teeth. Cavities restored with conventional RBC filling showed significantly worse values regarding fracture resistance compared to intact teeth.

Keywords: MOD cavity, short fiber-reinforced composite, resin-based composite filling, fiber net, fracture pattern 